\title{
JEREMIAS PELE: INTRODUZINDO A QUESTÃO RACIAL PARA CRIANÇAS E PRÉ-ADOLESCENTES
}

\author{
JEREMIAS PELE: INTRODUCING RACIAL ISSUES TO KIDS AND \\ PREADOLESCENTS
}

Silmara Ramos Fradico ${ }^{1}$

Emerson Inácio²

\begin{abstract}
Resumo: Este artigo apresenta a história em quadrinhos Jeremias Pele como recurso auxiliar para educadores que buscam utilizar a mídia quadrinhos em suas aulas. Será feita uma breve descrição da importância das histórias em quadrinhos no processo de aprendizado de crianças e adolescentes, e também se introduzirá o personagem Jeremias e o selo Graphic MSP. Em seguida se demonstrará como usar a história da novela gráfica tema do artigo, Jeremias Pele, nas aulas de interpretação de texto, vinculando as possíveis interpretações à discussão sobre o tema das questões raciais.
\end{abstract}

\begin{abstract}
This article presents the comic Jeremias Pele as an auxiliary resource for educators who seek to use comics in their classes. A brief description will be given of the importance of comic books in the learning process of children and adolescents, and the character Jeremias and the Graphic MSP label will be also introduced. Then how to use the story of the graphic novel theme of the article, Jeremias Pele, in text interpretation classes will be demonstrate, linking the possible interpretations to the discussion on the theme of racial issues.
\end{abstract}

Palavras-chave: Jeremias Pele; Novela gráfica; Racismo; Educação; Estereótipos; Bullying.

Keywords: Jeremias Pele; Graphic novel; Racism, Education; Stereotypes; Bullying.

\section{Introdução}

A sociedade tem avançado em vários aspectos, e mais do que nunca é imprescindivel que a escola acompanhe essas evoluções, que ela esteja conectada a essas transformações, falando a mesma língua, favorecendo o acesso ao conhecimento (...). (COSTA, 2012, p. 2)

O reconhecimento do valor das histórias em quadrinhos no processo de aprendizagem de pessoas de todas as idades data de um tempo considerável, tendo sido contempladas, inclusive, nos Referenciais Curriculares Nacionais para a Educação Infantil ${ }^{3}$ e nos Parâmetros Curriculares

1 Bacharel em Letras pela Universidade de São Paulo. Mestrando do programa de Estudos Comparados de Literaturas de Língua Portuguesa pela Universidade de São Paulo.

2 Doutor em Letras Vernáculas (UFRJ, 2006), Livre-docente (USP, 2015), é Professor Associado da Universidade de São Paulo na área de Estudos Comparados de Literaturas de Língua Portuguesa e bolsista de produtividade do CNPQ; investigador associado do Instituto Superior de Economia e Gestão, da Universidade de Lisboa, e do Instituto de Literatura Comparada Margarida Losa, da Universidade do Porto.

3 Conjunto de reflexões de cunho educacional sobre objetivos, conteúdos e orientações didáticas para os educadores que atuam diretamente com crianças de 0 a 6 anos. 
Nacionais ${ }^{4}$, além de vários títulos serem distribuídos através do Programa Nacional Biblioteca na Escola $^{5}$, desde 2007. A partir desse reconhecimento, a leitura de histórias em quadrinhos por parte dos professores e o uso destas nas atividades em sala de aula contribuiria para o quadro idealizado por Vera Lucia Pereira da Costa para a escola: estar "conectada a essas transformações, falando a mesma língua". Contudo, nem todos os professores incluem histórias em quadrinhos em seus programas, limitando o contato de crianças e adolescentes com esta forma de arte às tirinhas presentes nos livros didáticos e provas oficiais. Esta realidade se dá por diversos motivos: falta de contato dos adultos com histórias em quadrinhos, nenhuma orientação ou treinamento para seu uso nos cursos de formação de professores, simples desinteresse, dúvidas quanto à aplicabilidade em aula e a lista segue com outros motivos que exigiriam uma pesquisa mais profunda.

As histórias em quadrinhos oferecem atrativos visuais e narrativos que servem de incentivo à leitura e ao trabalho de interpretação de texto. Além disso, a narrativa gráfica — que inclui não apenas histórias em quadrinhos, como também charges e outras mídias que priorizam a ilustração como ferramenta principal da narrativa - quando bem trabalhada pelos seus autores, pode auxiliar no ensino da escrita de ficção, uma vez que um bom roteiro de quadrinhos apresenta uma estrutura mais marcada e melhor definida, sobretudo em aspectos como descrição, passagem de tempo, construção de personagens, ponto de vista do narrador e sequências de ação.

Tendo em vista a aprendizagem de crianças e adolescentes, um estudante que tenha contato com narrativas gráficas durante a infância poderá apresentar maior facilidade para organizar argumentações em debates e textos dissertativos, além de ter mais facilidade para criar e interpretar textos, devido a uma característica exclusiva das narrativas visuais que trabalha e exercita estas habilidades cerebrais: o lapso de tempo, recurso utilizado para ligar os quadros entre si. O espaço entre um quadro e outro é completado pela criação do leitor, que interpreta e complementa a sequência dos fatos. Um quadro isolado é difícil de entender, porém, a ordem dos quadros, acrescida do que é imaginado pelo leitor no lapso de tempo entre eles, é que dá sentido à história. Um leitor acostumado às narrativas das histórias em quadrinhos forma esta linearidade de modo automático.

Histórias em quadrinhos também utilizam com frequência metáforas visuais, conforme os quadros selecionados para análise neste artigo irão demonstrar, para facilitar a compreensão dos sentimentos dos personagens ou das consequências de alguma ação. Crianças e adolescentes que tenham contato com metáforas visuais podem desenvolver mais facilmente a habilidade de ler as emoções das pessoas de seu convívio.

Ainda sobre as vantagens do uso de histórias em quadrinhos na escola, em 2001 a Confederação

4 Diretrizes elaboradas pelo Governo Federal que orientam a educação, separadas por disciplina.

5 Programa do Governo Federal criado em 1997. Distribui obras de literatura, de pesquisa e de referência às escolas públicas do país. 
Nacional dos Trabalhadores em Educação ${ }^{6}$ realizou a pesquisa Retratos da Escola 2 com os seguintes resultados:

\begin{abstract}
Alunos que leem gibis têm melhor desempenho escolar do que aqueles que usam apenas o livro didático. A HQ aumenta significativamente a performance do aluno: entre os que acompanham quadrinhos, o percentual das melhores notas nas provas aplicadas foi de $17,1 \%$, contra $9,9 \%$ entre os que não leem. Mais ainda, essa pesquisa mostra que professores que leem revistas em quadrinhos obtêm melhor rendimento dos alunos, pois conhecem melhor o universo dos estudantes e se aproximam deles usando exemplos desse universo como paradigma para as aulas (...). Na rede pública, 36\% dos alunos de leitores de gibis têm proficiência média-alta e alta, contra $31,5 \%$ dos não leitores. Na rede particular, 50\% dos estudantes de educadores que leem gibis têm proficiência alta, contra $45,9 \%$ dos que não leem. (...) o que nos mostra a importância de haver tempo livre para apreensão de conhecimento e de vivência de outras fontes para a qualidade da educação. (CARVALHO, 2006, p. 38-39)
\end{abstract}

Tendo estabelecido a relevância das histórias em quadrinhos na escola, antes de prosseguir na abordagem do uso do livro em questão - Jeremias Pele — este artigo contará com uma apresentação sucinta do selo Graphic MSP, ao qual pertence a obra tratada, e do surgimento e trajetória do personagem título.

Jeremias foi um dos primeiros personagens criados por Maurício de Souza e também um dos primeiros a serem publicados, em março de 1960, na primeira história do autor, antes mesmo da Mônica ou de qualquer dos personagens principais da Rua do Limoeiro. Ele e os outros meninos da Turma do Bermudão - Franjinha, Manezinho e Titi — são mais velhos que as outras crianças e não aparecem tanto nas histórias. Assim como outros personagens, Jeremias ganhou mais destaque nas revistas Turma da Mônica Jovem, linha voltada para adolescentes. Em sua edição do selo Graphic MSP o personagem também galgou novos patamares, sendo representado em histórias antes mesmo de ter seu próprio título. É o caso, por exemplo, de Bidu Juntos, em que Jeremias é apresentado como amigo de Franjinha e dono do cachorro Manfredo, amigo de Bidu.

O selo Graphic MSP foi idealizado em 2009, a partir do projeto MSP 50, em que os personagens tradicionais de Maurício de Souza foram reimaginados por diversos desenhistas brasileiros de dentro e de fora do mercado nacional de quadrinhos. O projeto consiste em publicar histórias independentes, com traço e enredo à livre escolha dos autores convidados, em formato novela gráfica.

6 Criada em 1945 e estabelecida definitivamente em 1990, é a estrutura unificada das várias Federações setoriais da educação do Brasil.

7 As imagens, personagens e histórias, bem como suas distintas semelhanças, apresentadas neste artigo, compõem a história em quadrinhos intitulada Jeremias Pele e são propriedade da Maurício de Sousa Produções - salvo quando indicado. Todos os direitos reservados. 
As novelas gráficas possuem histórias únicas, fugindo ao padrão tradicional das publicações de histórias em quadrinhos de um modo geral, incluindo as histórias mensais da Turma da Mônica, nas quais as narrativas não parecem seguir um fluxo temporal - daí a atribuição do nome "publicação em linha" para essas publicações mensais. As novelas gráficas também se diferenciam por serem publicadas em formato livro, nunca em revistas ou fascículos. As histórias do selo Graphic MSP são voltadas para pré-adolescentes, adolescentes e adultos, diferentemente das revistas da Turma da Mônica, cujo público-alvo são crianças, muitas das quais sem idade para serem alfabetizadas.

A primeira publicação do selo aconteceu em 2012, com Astronauta Magnetar, alcançando grande sucesso de crítica e vendas. Títulos como Bidu Caminhos e Penadinho Vida foram traduzidos e vendidos na França. O livro Jeremias Pele, roteirizado por Rafael Calça e desenhado por Jefferson Costa, esgotou rapidamente nas livrarias e venceu o prêmio Jabuti em 2019 na categoria História em Quadrinhos.

Durante este artigo, serão utilizados todos os termos já relacionados para se referir à obra Jeremias Pele: história em quadrinhos, quadrinhos, novela gráfica, graphic novel e livro.

\section{Jeremias Pele}

Antes de prosseguir com a análise dos quadros selecionados, apresentaremos um resumo da trama. Na história, Jeremias é filho de um casal que trabalha como profissionais liberais no ramo da arquitetura. Leva uma vida comum e confortável, com uma boa casa, um bom ambiente familiar e frequentando a escola.

Um dia, na escola, a professora apresenta para os alunos a seguinte atividade: pesquisar sobre a profissão designada em aula, redigir uma redação e apresentá-la para a turma. Aos colegas de Jeremias, a professora designa profissões como médica, ator e advogado, para Jeremias, pedreiro. As crianças riem uma primeira vez. Jeremias sugere pesquisar e escrever sobre ser astronauta. Nova onda de risos dos colegas. A professora não tenta intermediar a situação e ainda completa respondendo ao menino que astronauta é uma profissão muito incomum. E mais uma vez os colegas riem do menino, sem intervenção da professora.

No decorrer da narrativa, Jeremias tenta lidar com este conflito enquanto vivencia situações de racismo tanto na escola, da parte dos colegas, quanto nas ruas, da parte de conhecidos e desconhecidos. O único apoio que recebe parte dos familiares, sendo desamparado até mesmo pelo seu melhor amigo. Em certo ponto da história, o garoto tenta descaracterizar o cabelo, alvo das piadas dos colegas. $\mathrm{O}$ lenitivo vem apenas quando ao sair para conversar com os pais, o menino se depara com uma HQ que estampa um protagonista negro na capa. 
No momento de apresentar sua redação para a turma da escola, o menino não titubeia em usar o aparato de proteção de pedreiro, cedido por seu avô. No texto que lê para a classe, o resultado de sua pesquisa soa diferente dos demais, questionando estereótipos de raça e discorrendo sobre a postura da sociedade com relação a esses estereótipos. Ao fim da história, Jeremias ostenta o presente de seu avô para ele: a tradicional boina vermelha.

\section{Jeremias Pele na sala de aula}

Caso haja uma necessidade imprescindível de classificar a utilização de Jeremias Pele dentro das competências a serem aprendidas pelos jovens na escola, poderíamos enquadrar este uso como ensino ou prática de interpretação de textos. Ao contrário do que se acredita: que os quadrinhos trariam as mensagens prontas, sem necessidade de decodificação devido à junção de imagens e palavras, os quadrinhos oferecem excelentes oportunidades ao exercício da interpretação, tanto pela intertextualidade com outros textos literários, quanto pelas questões semióticas do uso das imagens; também, pela necessidade do leitor preencher as lacunas narrativas quadro a quadro, página a página - o lapso de tempo citado na introdução. Ler histórias em quadrinhos, portanto, é interpretar as ideias dos autores, expressas na relação entrelaçada entre palavras e imagens.

A partir de agora, trechos da novela gráfica serão apresentados e terão sua possível aplicabilidade em aula comentada. Sendo estas possíveis aplicabilidades, sugestões de uso, pensadas como pontos de partida para atividades de interpretação de textos, nas quais podem e devem ser ampliadas, adequadas e modificadas. Os quadros selecionados de Jeremias Pele e seus respectivos comentários não estarão necessariamente em ordem cronológica, mas sequenciados por tema.

Conforme o título deste artigo, e o próprio tema da obra, a atividade ou atividades de interpretação de textos servirão como oportunidade de tratar o tema da graphic novel — estereótipos de raça — em sala de aula, com crianças e adolescentes com idades em torno da classificação indicativa da obra: 12 anos.

Nas figuras 1 e 2, vemos o momento da distribuição de profissões entre os alunos. A professora atribui a Jeremias a profissão de pedreiro, ouvindo de volta o pedido do menino para escrever sobre ser astronauta. Os colegas de classe riem, e a professora responde negativamente. Esta sequência pode ser utilizada tanto em uma discussão quanto aos estereótipos de raça, quanto num debate sobre a autonomia das crianças em relação aos adultos em sala de aula. 


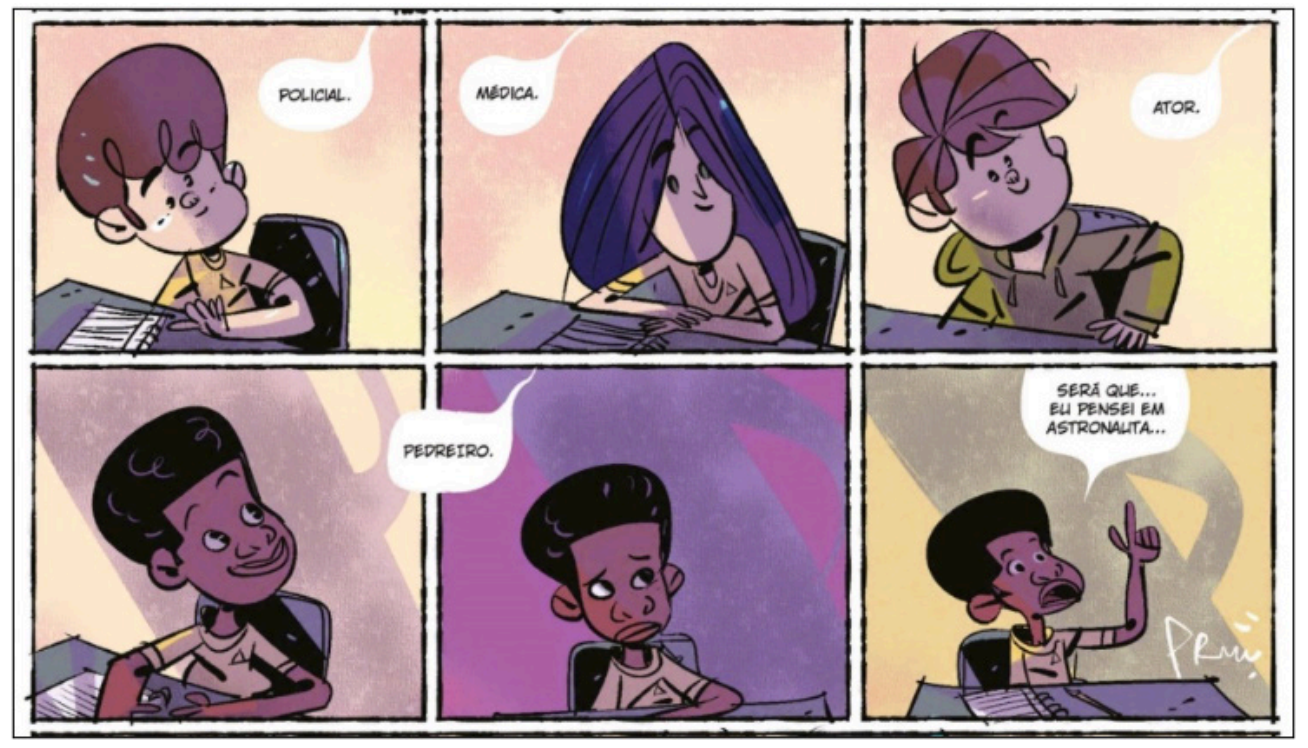

Figura 1: quadro ilustrado, Jefferson Costa. Jeremias Pele. São Paulo: Panini, 2018.

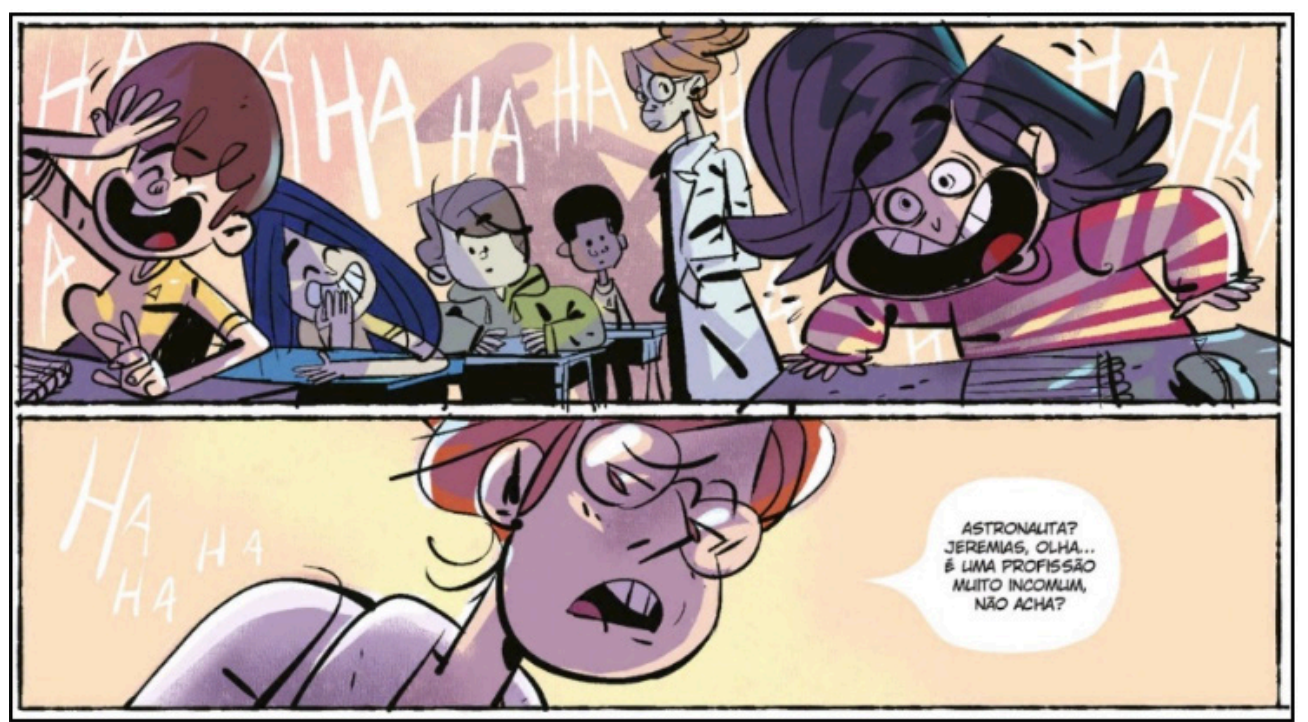

Figura 2: quadro ilustrado, Jefferson Costa. Jeremias Pele. São Paulo: Panini, 2018.

Na figura 3, os personagens estão no que parece ser um museu. O personagem Johny faz troça com a aparência de Jeremias, relembrando o momento na sala de aula em que o menino pediu para escrever sobre astronautas. A "brincadeira" parte da ideia de que o cabelo de Jeremias não caberia no capacete de astronauta. O professor ou professora pode introduzir a questão das tais "brincadeiras", estabelecendo um debate entre as crianças ou adolescentes sobre o quanto esse tipo de comentário é saudável ou não, e seguir pedindo que os alunos elaborem as diferenças entre provocações genéricas e ofensas racistas. 


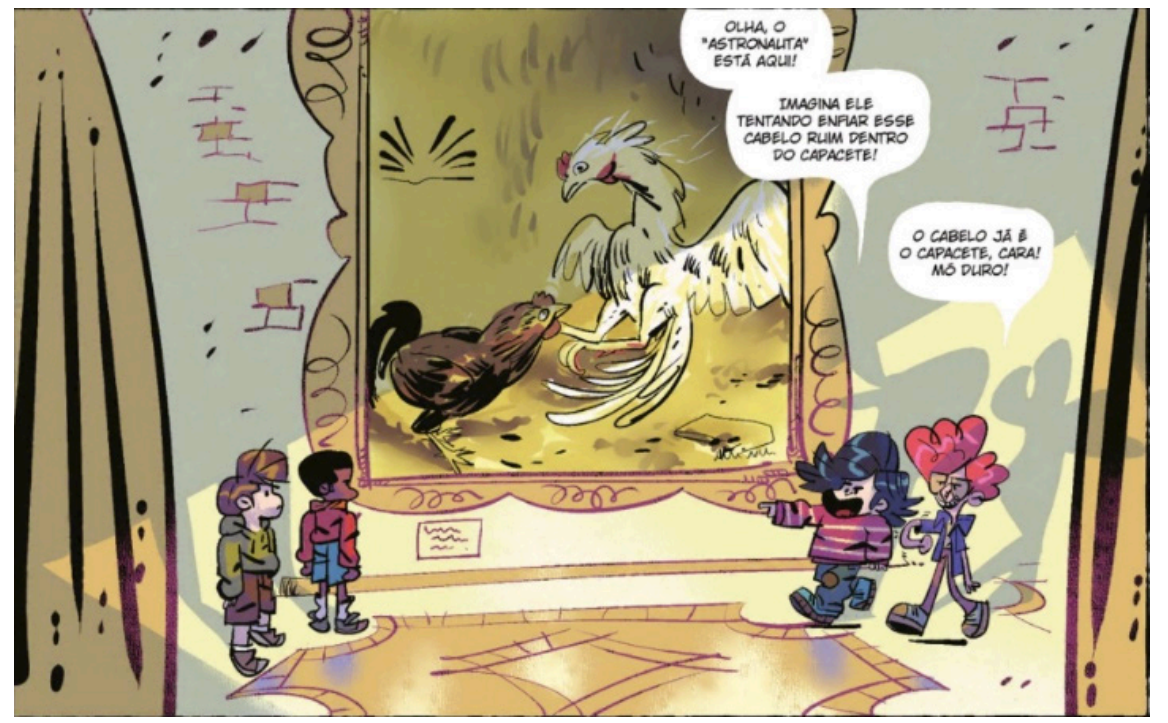

Figura 3: quadro ilustrado, Jefferson Costa. Jeremias Pele. São Paulo: Panini, 2018

A discussão pode prosseguir utilizando outros quadros e cenas da HQ, como as seguintes:

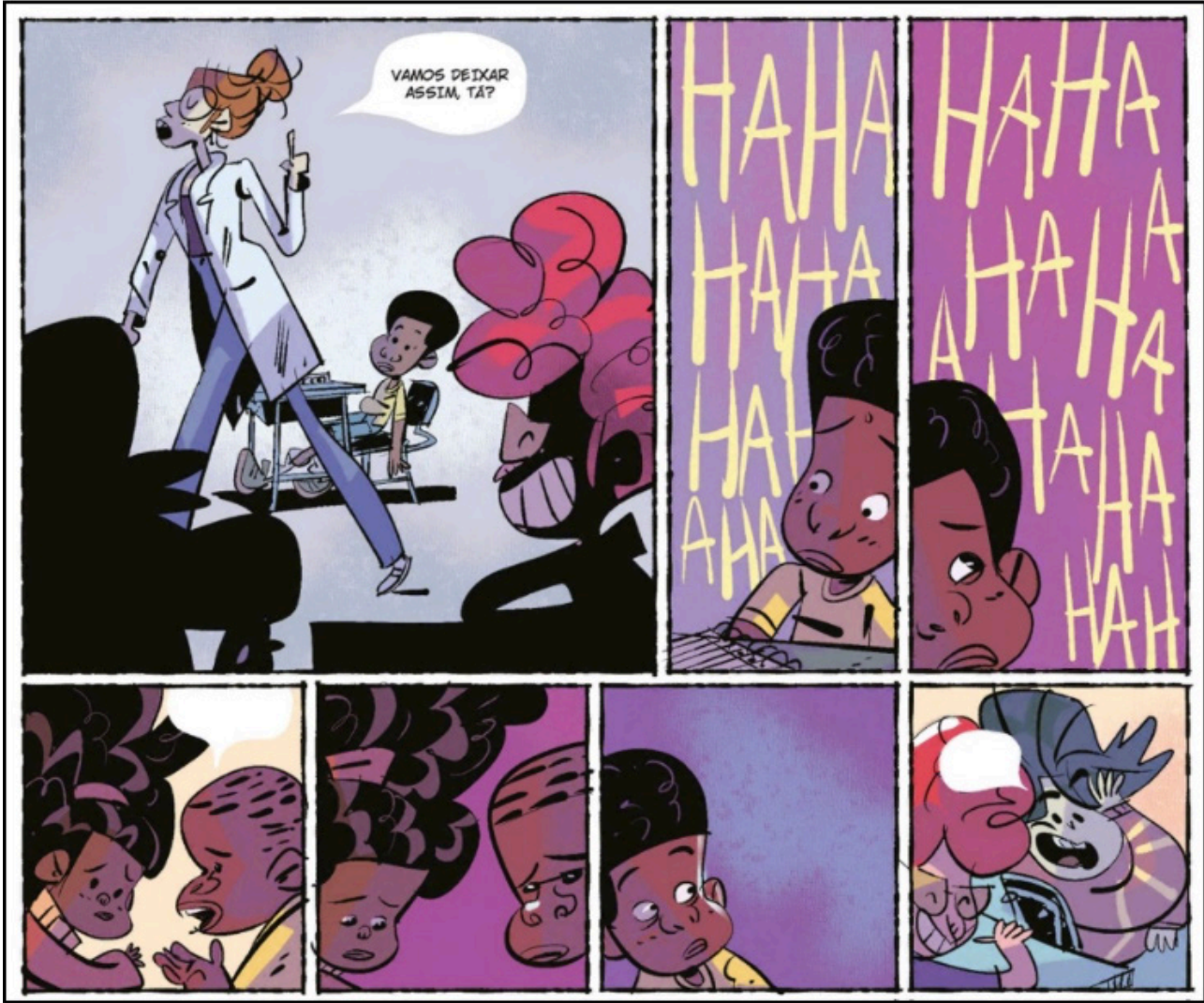

Figura 4: quadro ilustrado, Jefferson Costa. Jeremias Pele. São Paulo: Panini, 2018 


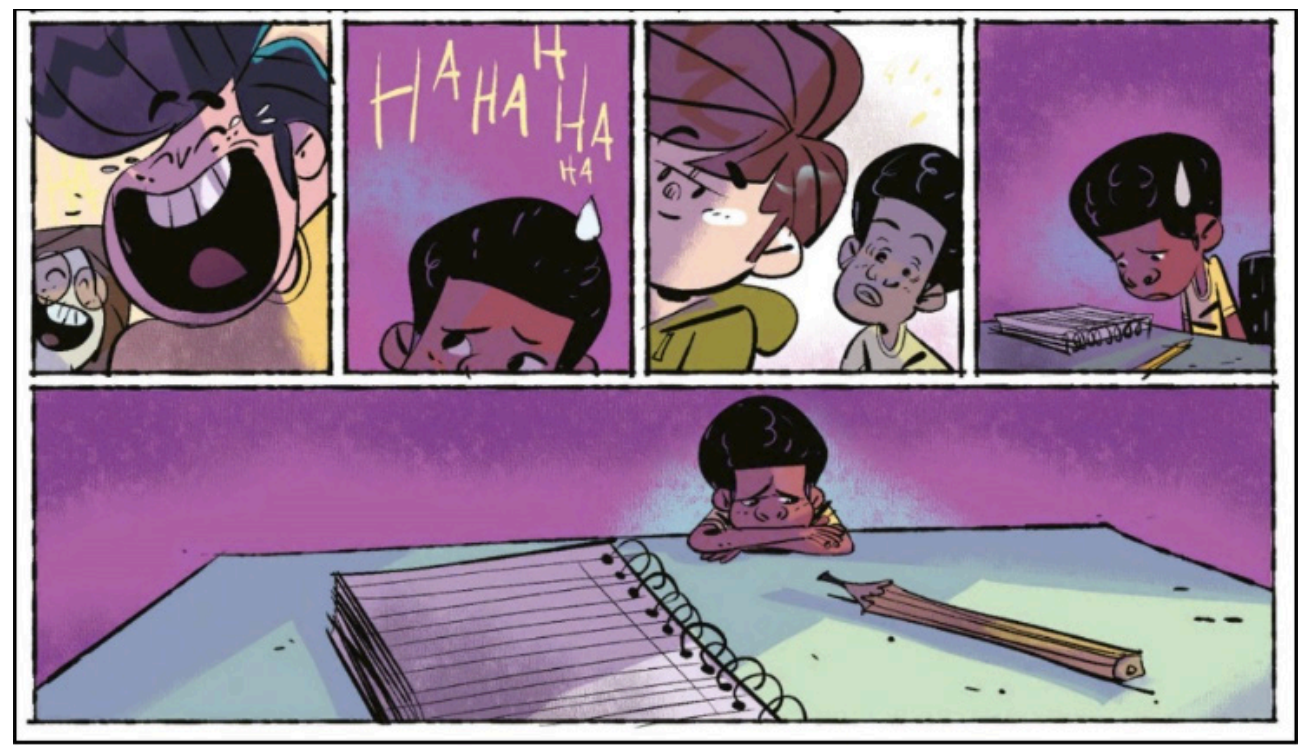

Figura 5: quadro ilustrado, Jefferson Costa. Jeremias Pele. São Paulo: Panini, 2018

Conforme as figuras 4 e 5 mostram, os personagens riem de Jeremias após ter negada sua tentativa de escrever sobre astronautas. Toda a turma ri, exceto dois colegas que também são negros. Tanto a primeira imagem quanto a segunda não apresentam a professora intervindo em momento algum. Os educadores podem guiar a discussão para o tema da exclusão e também pedir para que os alunos discorram sobre o papel dos adultos no combate ao bullying e às suas consequências. Caso os profissionais de educação prefiram outro ponto de partida para tratar do tema com os alunos, utilizando a obra como base para uma atividade de interpretação de textos, a figura 6 também oferece uma boa introdução:

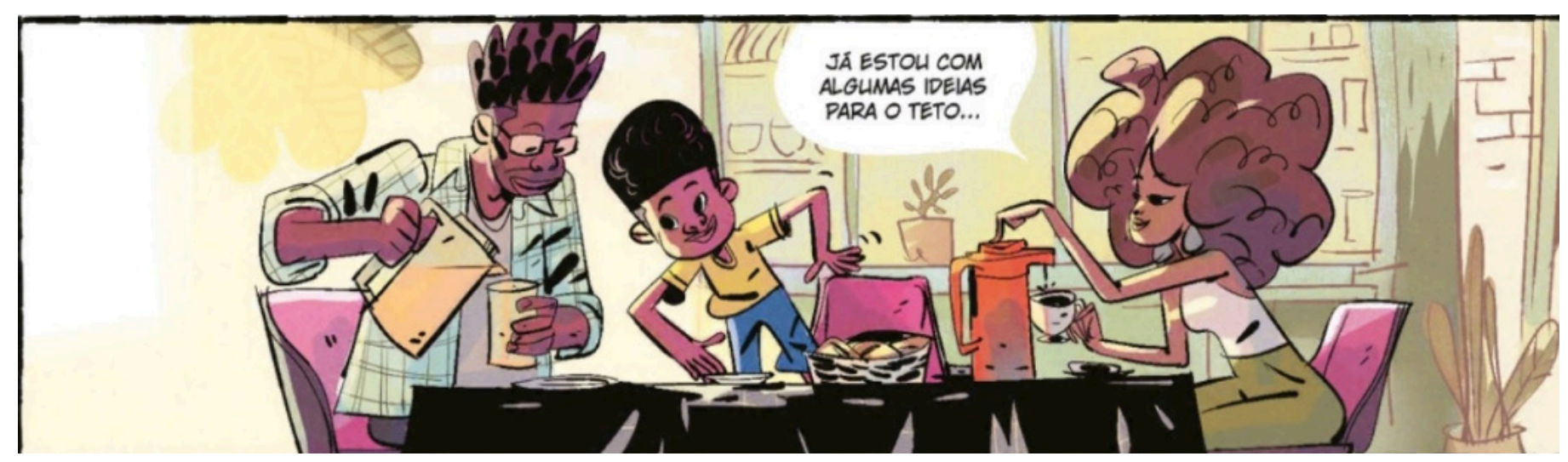

Figura 6: quadro ilustrado, Jefferson Costa. Jeremias Pele. São Paulo: Panini, 2018 
Na figura 6 vemos uma clara representação de cabelos crespos volumosos e com formas bem definidas. O professor ou professora pode apresentar o quadro e perguntar aos alunos com que frequência encontram pessoas com cabelos como os da família de Jeremias, ou quantos profissionais conseguem se lembrar que tenham cabelos parecidos. Também é possível fazer um comparativo entre gerações, com o educador comentando como era quando tinha a idade dos alunos.

Outra discussão que pode ser levantada a partir de Jeremias Pele, e que circunda o tema principal do livro, é quanto ao racismo estrutural. Este é um assunto difícil de abordar e demonstrar mesmo entre adultos, mas a narrativa da história em quadrinhos apresenta um formato ilustrativo e interpretativo diferente de todas as outras mídias, facilitando a apresentação de determinados conceitos, como podemos ver nas figuras 7, 8 e 9, que apresentam uma abordagem policial. Nestes quadros, o pai de Jeremias é abordado e revistado. Os policiais o encostam à parede, verificam seus documentos e reviram seu material de trabalho, jogando-o no chão, enquanto fazem chacota do fato de ele ser arquiteto.

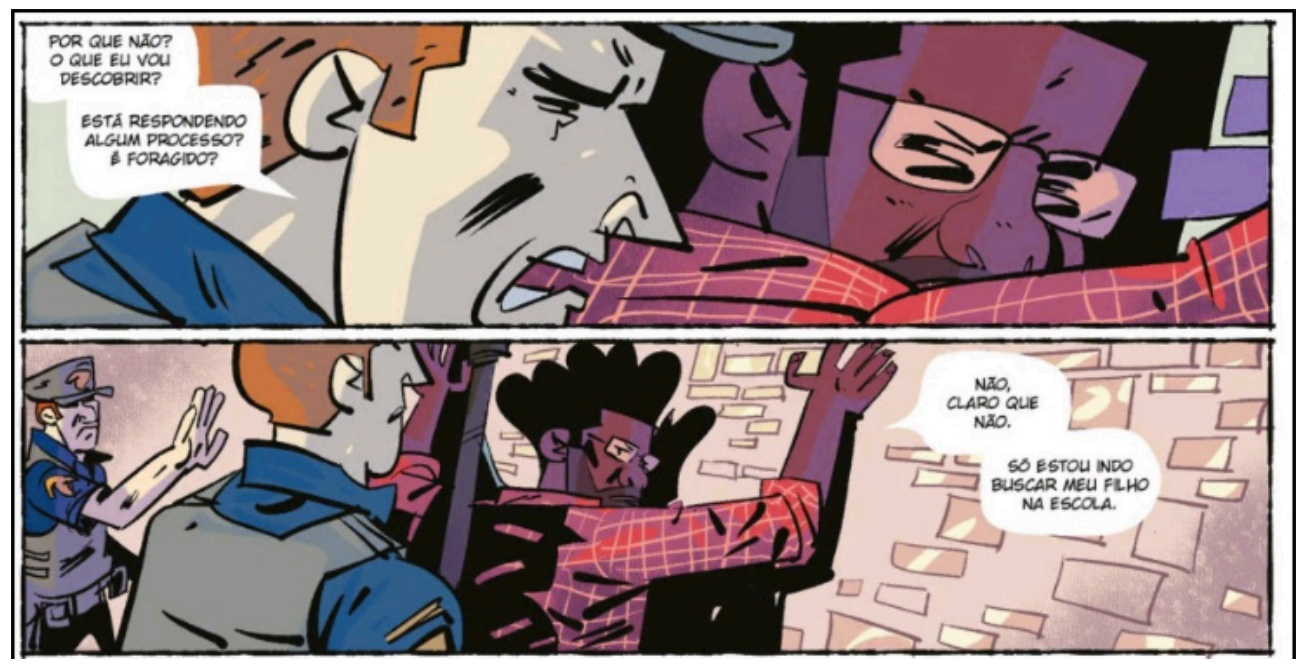

Figura 7: quadro ilustrado, Jefferson Costa. Jeremias Pele. São Paulo: Panini, 2018. 


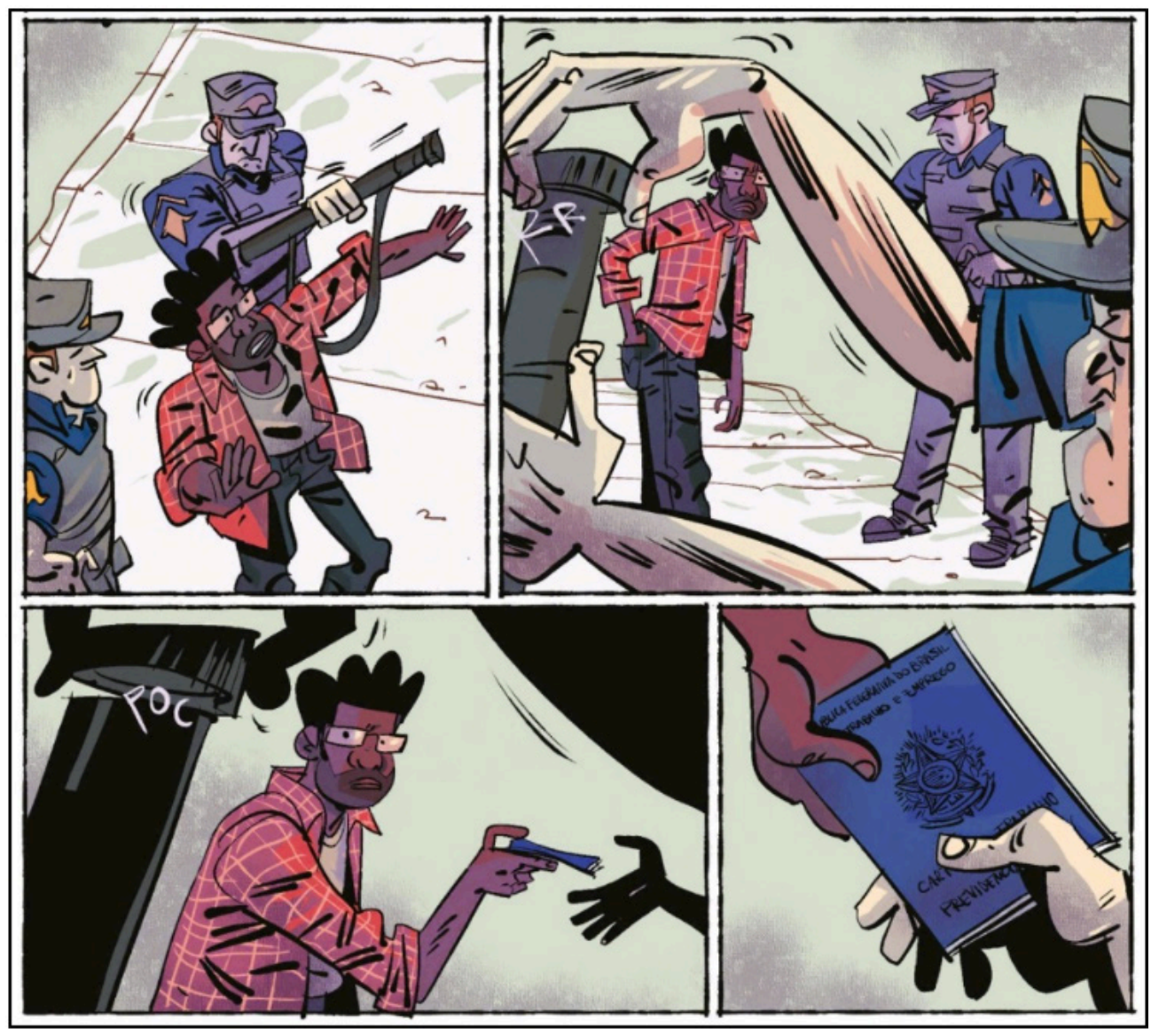

Figura 8: quadro ilustrado, Jefferson Costa. Jeremias Pele. São Paulo: Panini, 2018.

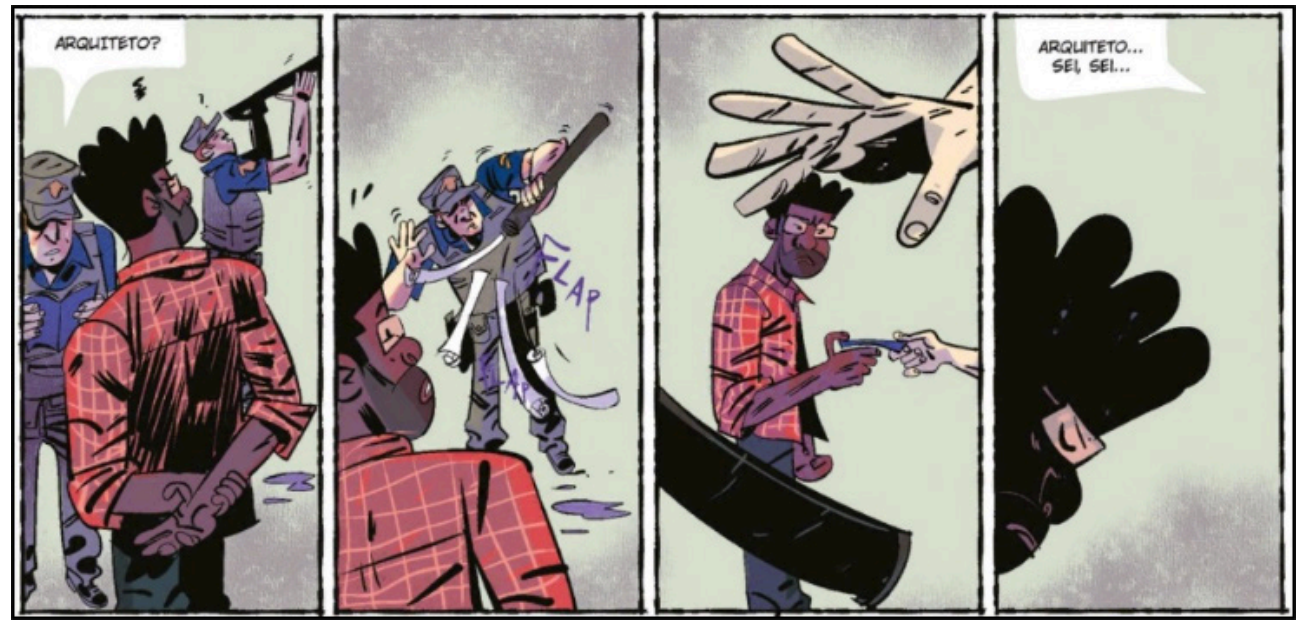

Figura 9: quadro ilustrado, Jefferson Costa. Jeremias Pele. São Paulo: Panini, 2018. 
Os professores podem questionar em quais situações os alunos acham que alguém é parado e revistado pela polícia e prosseguir com o debate perguntando se eles acham que existe alguma relação entre estereótipos raciais e o modo como as autoridades tratam as pessoas. Se preferirem, podem substituir as figuras 7,8 e 9 pelas figuras 10 e 11 ou usá-las em conjunto.

Nas figuras 10 e 11 vemos os personagens que hostilizam Jeremias se afastando do protagonista e de seu amigo. $\mathrm{O}$ amigo, Marcos, tenta disfarçar que está rindo da piada feita pelos outros garotos. Jeremias se afasta de Marcos enquanto este tenta amenizar as ofensas feitas pelos outros personagens.

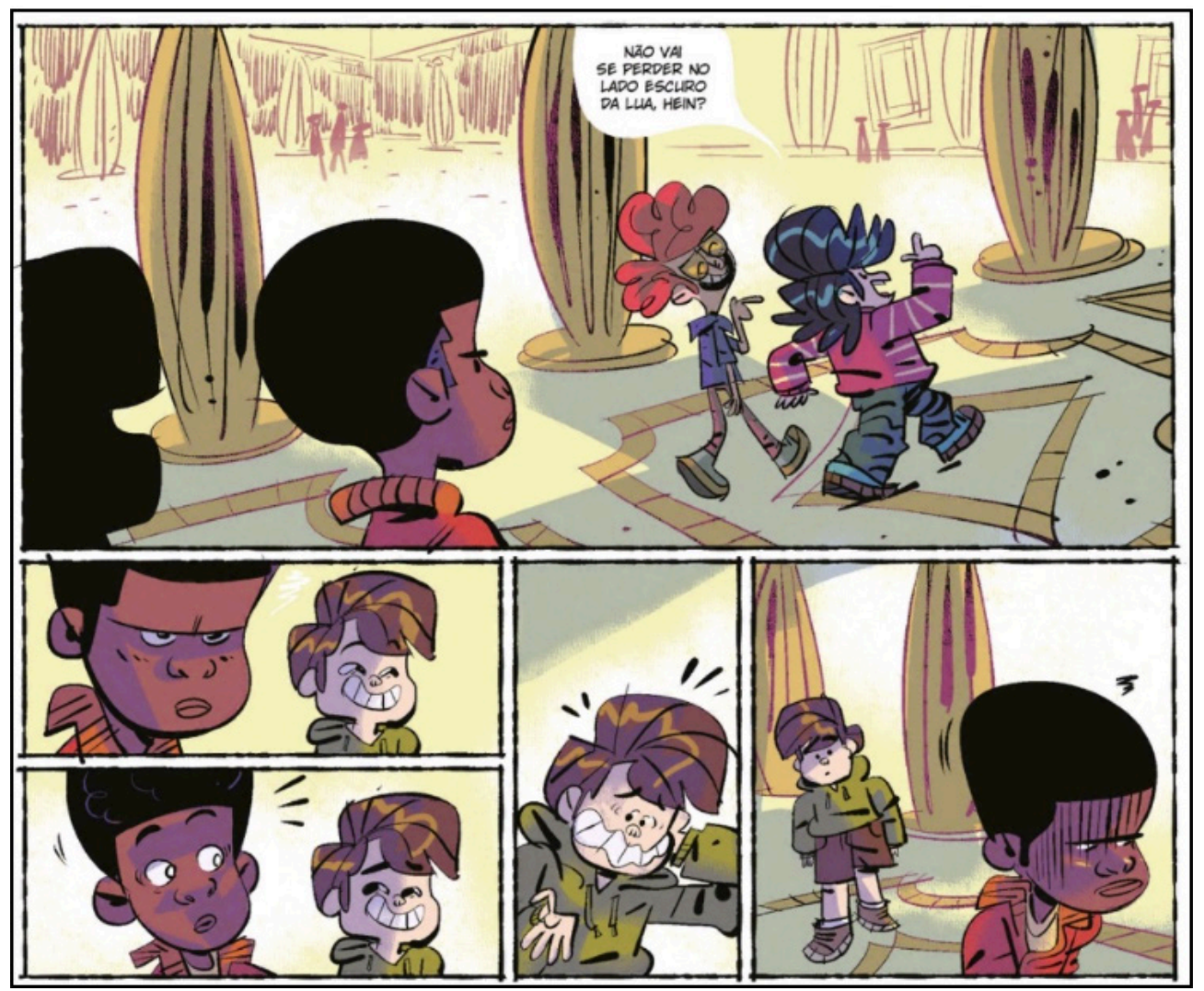

Figura 10: quadro ilustrado, Jefferson Costa. Jeremias Pele. São Paulo: Panini, 2018. 


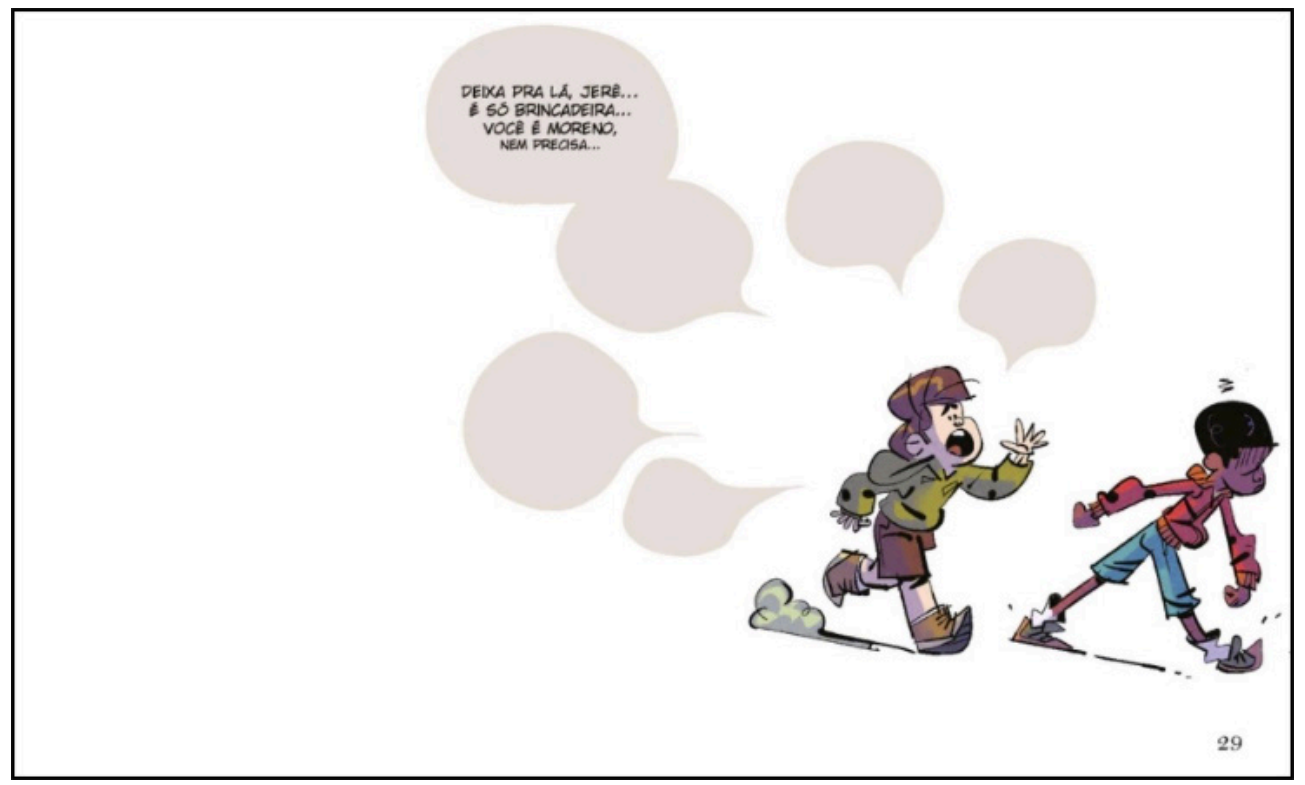

Figura 11: quadro ilustrado, Jefferson Costa. Jeremias Pele. São Paulo: Panini, 2018.

É possível conduzir a discussão perguntando aos alunos por qual motivo eles acham que o amigo do protagonista riu e tentou se justificar dizendo que a ofensa era "só brincadeira", e, a partir daí, voltar ao debate sobre o bullying e as tais "brincadeiras", já sugerido em um dos parágrafos anteriores. Caso haja interesse em manter o assunto bullying, uma abordagem já apresentada e que pode ser adotada a partir de mais de um quadro ou passagem do livro, é a participação dos pais e adultos na prevenção e solução do problema usando, por exemplo, a figura 12.

Nestes quadros vemos a mãe de Jeremias conversando com o garoto, que em princípio se mostra contrariado, sobre a profissão de pedreiro, e tentando tirar do menino as impressões estereotipadas que ele mesmo apresenta no início do conflito relacionado à atividade sugerida pela professora mais cedo. 


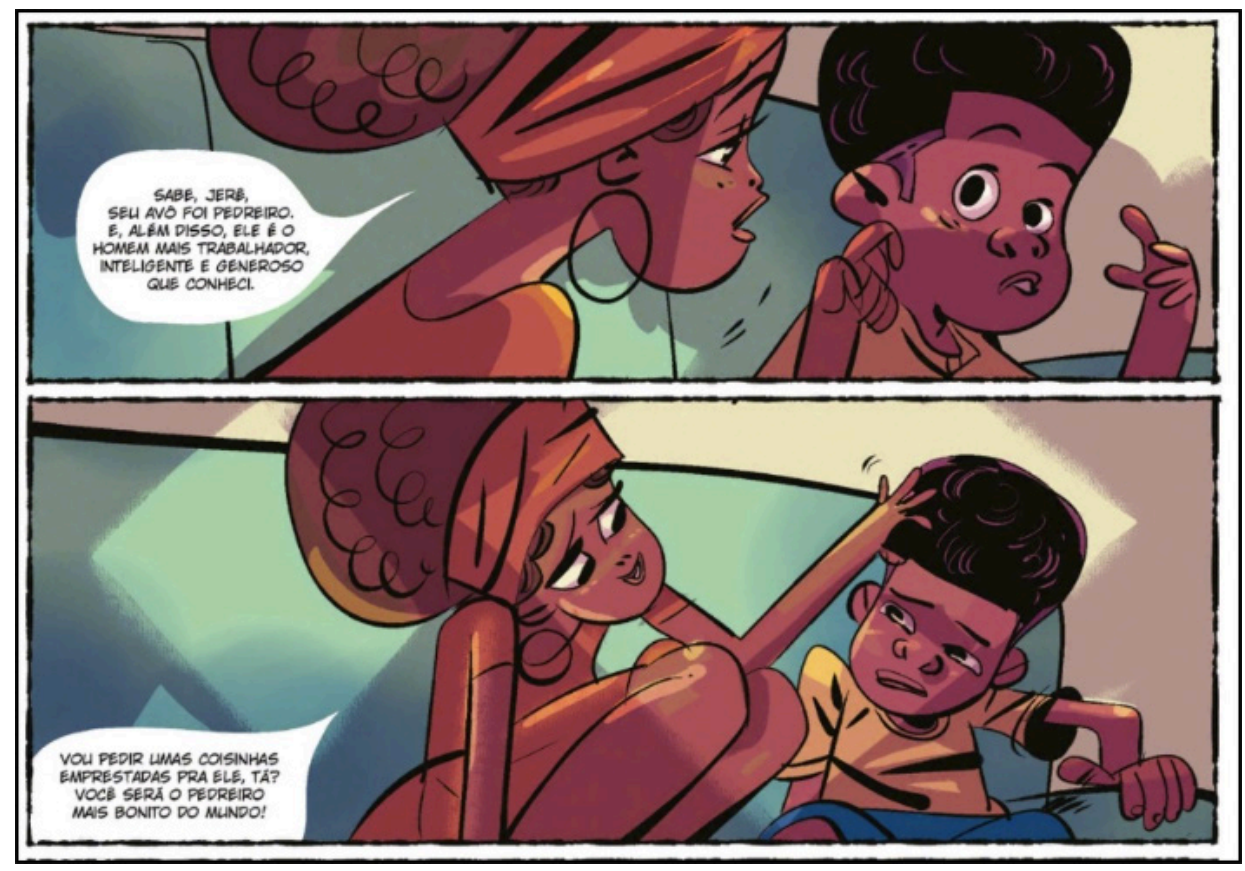

Figura 12: quadro ilustrado, Jefferson Costa. Jeremias Pele. São Paulo: Panini, 2018.

Assim como o uso da figura 12 pode sinalizar a participação dos pais como uma solução para conflitos, a graphic novel apresenta outros momentos que podem enveredar para as soluções ou medidas de prevenção às situações mostradas na história, como os ilustrados nas figuras 13 e 14 , que apresentam Jeremias trajado com a indumentária de proteção característica dos profissionais da construção civil, enquanto lê algumas linhas de sua redação. Ele é interrompido pela professora, que questiona o conteúdo de seu texto, uma vez que a introdução trata de um personagem de história em quadrinhos, e não da profissão de pedreiro. O garoto não se intimida e continua sua leitura, abordando o momento da distribuição das profissões por parte da professora, sugerindo indiretamente as implicações: o menino negro ter sido escolhido para escrever sobre ser pedreiro. Em sua leitura também admite que, em princípio, ele mesmo teve vergonha da ocupação sugerida em aula, mas que essa vergonha se tornou em outra, ao perceber que estava apegado a um estereótipo, e complementa ressaltando a importância da profissão. 


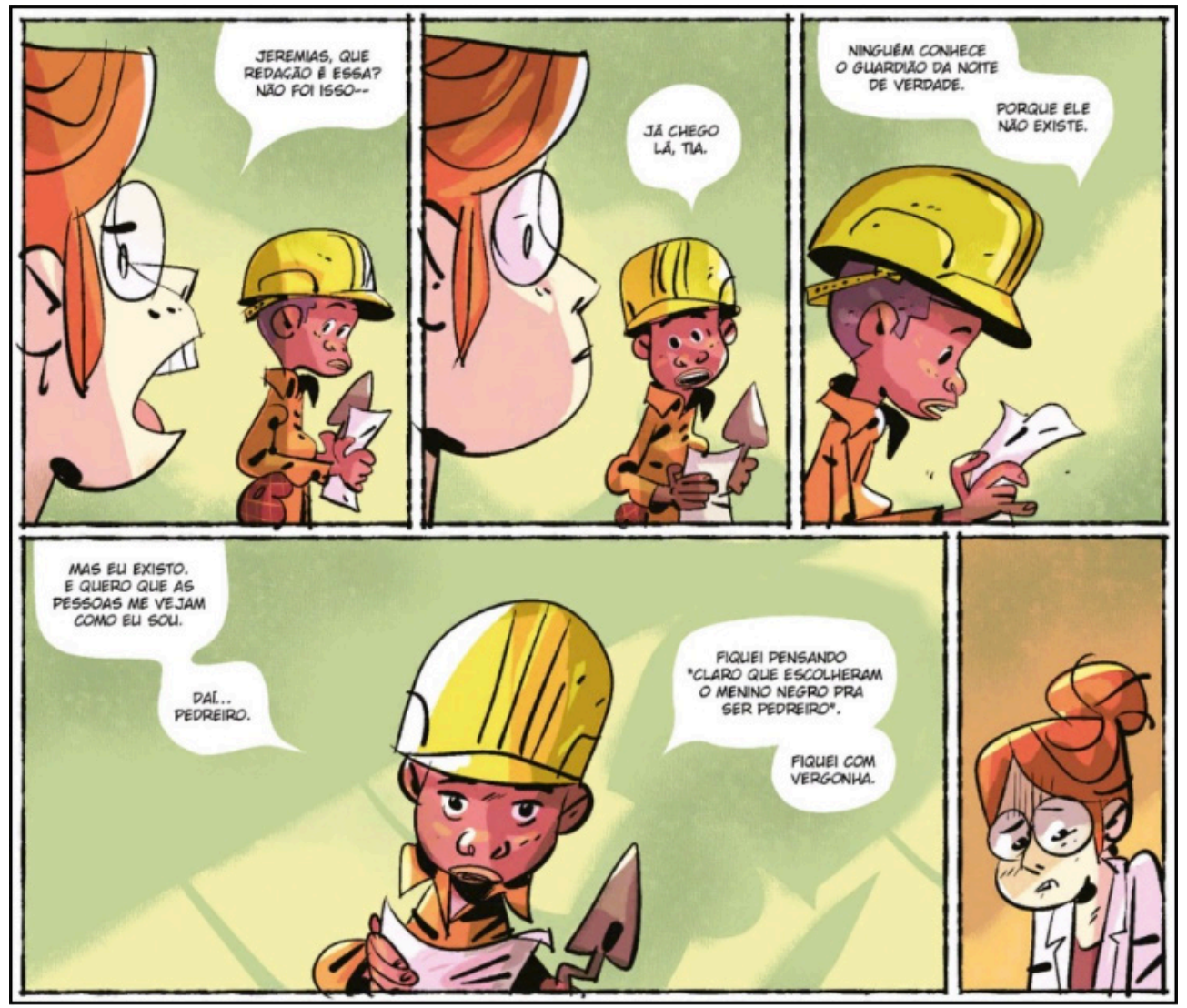

Figura 13: quadro ilustrado, Jefferson Costa. Jeremias Pele. São Paulo: Panini, 2018.

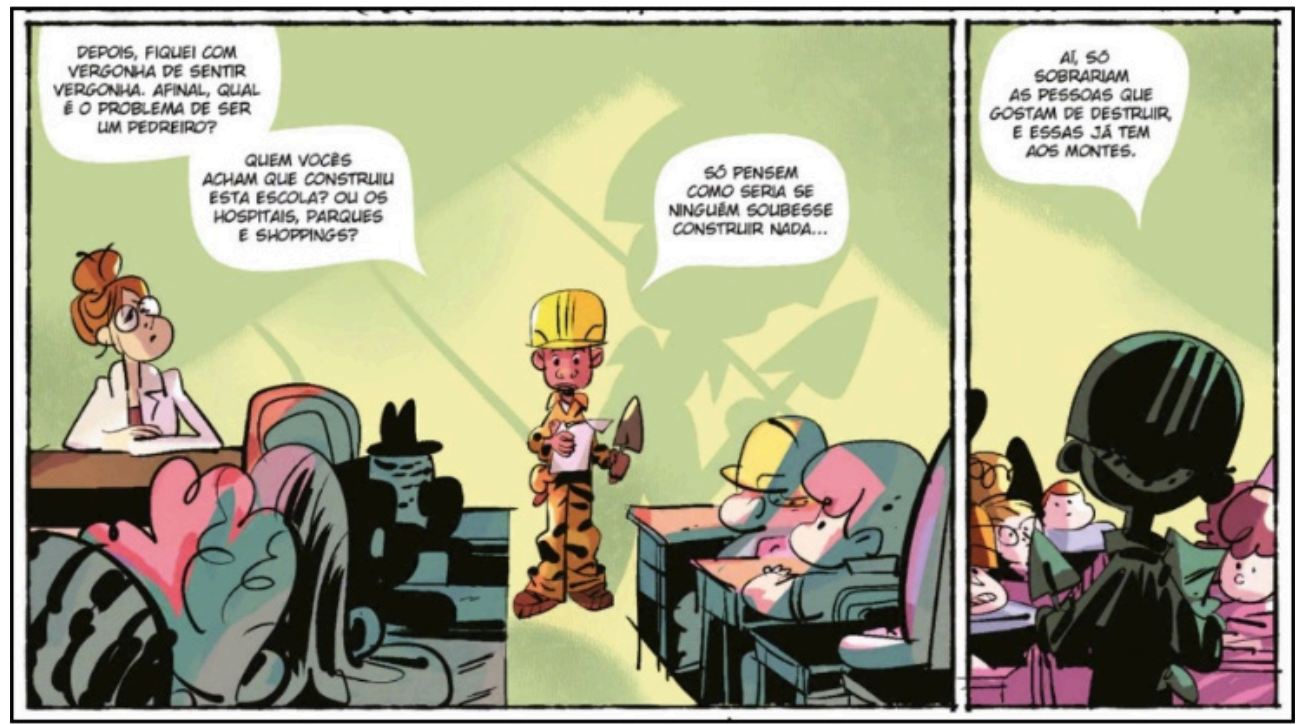

Figura 14: quadro ilustrado, Jefferson Costa. Jeremias Pele. São Paulo: Panini, 2018. 
Utilizando as figuras 13 e 14, os professores podem comentar sobre como não existem sentimentos negativos e como não é errado senti-los ou expressá-los, perguntando aos alunos quais as formas corretas de expressar esses sentimentos, segundo o que eles acham. Também podem perguntar aos alunos se eles acham correto que crianças, adolescentes e jovens questionem os adultos e as autoridades, e sobre quais as melhores formas de resolver conflitos de gerações, tendo como base as figuras 15 e 16, nas quais vemos Jeremias ler o restante de sua redação. Nos quadros, o menino tira o capacete e exibe seu novo corte de cabelo. Enquanto revela com orgulho que seu avô é pedreiro, ao mesmo tempo discorre sobre as experiências e conversas que teve com sua família durante o intervalo de tempo em que realizava a atividade demandada pela professora no início da história, que gerou situações de embaraço e desconforto para ele, e, que não foram mediadas pela professora.

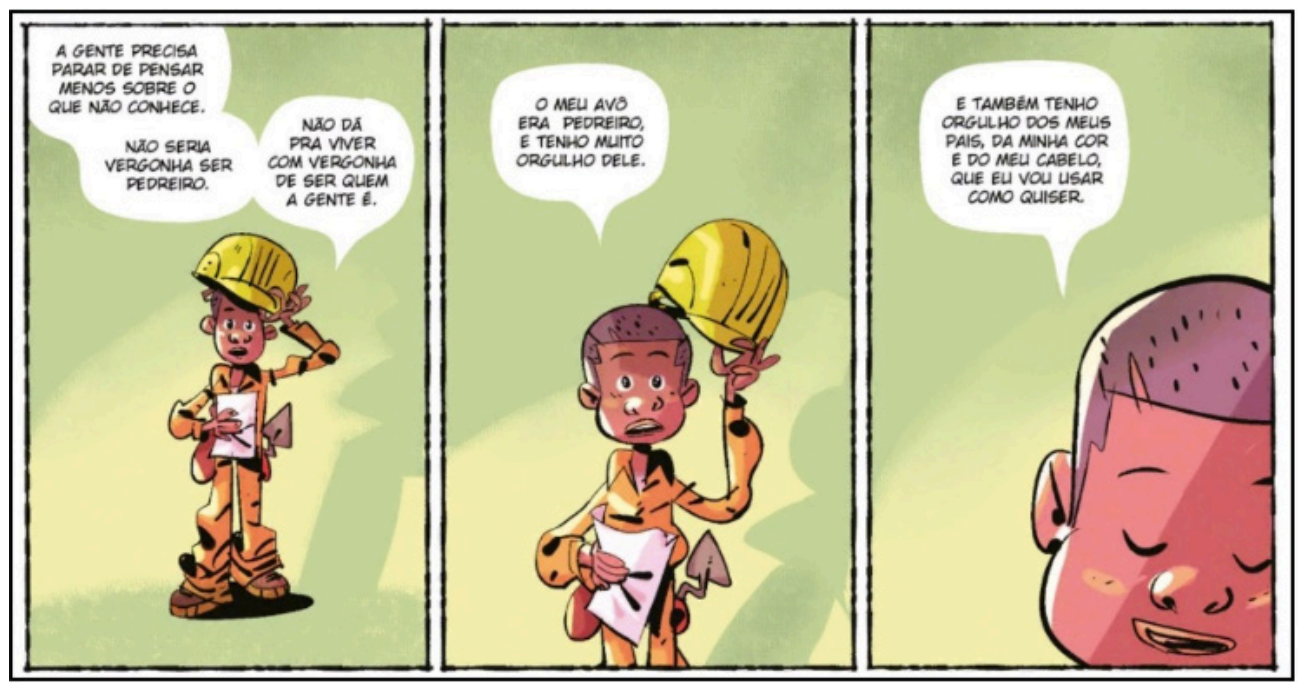

Figura 15: quadro ilustrado, Jefferson Costa. Jeremias Pele. São Paulo: Panini, 2018. 


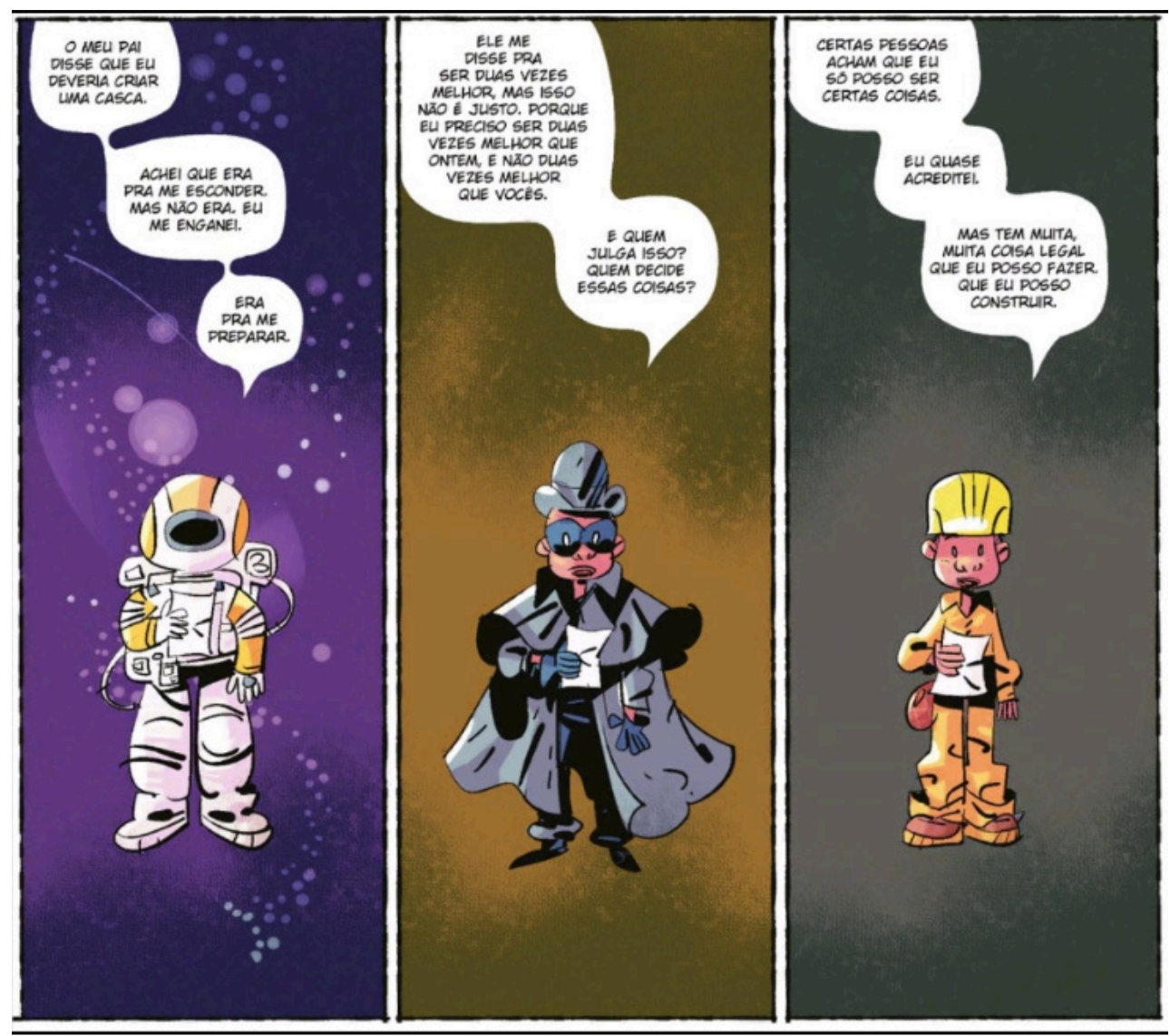

Figura 16: quadro ilustrado, Jefferson Costa. Jeremias Pele. São Paulo: Panini, 2018.

Para fechar o debate, relacionando os pontos que foram discutidos entre os alunos com uma mensagem positiva, não somente relacionada ao tema, mas presente na história analisada, pode-se falar sobre como os estereótipos, o bullying, as experiências da infância e a representatividade na mídia e na sociedade influenciam na construção da identidade, usando as figuras 17 e 18 .

Nestes quadros, vemos Jeremias questionando o posicionamento de seu amigo durante os momentos em que foi atacado por conta da cor da sua pele e da textura de seu cabelo. Em seguida, o protagonista coloca a boina vermelha característica do personagem nas histórias tradicionais da Turma da Mônica e o vemos se separar do colega de escola com uma expressão resignada, indo ao encontro do avô, quando sua expressão muda completamente, demonstrando surpresa e felicidade. 


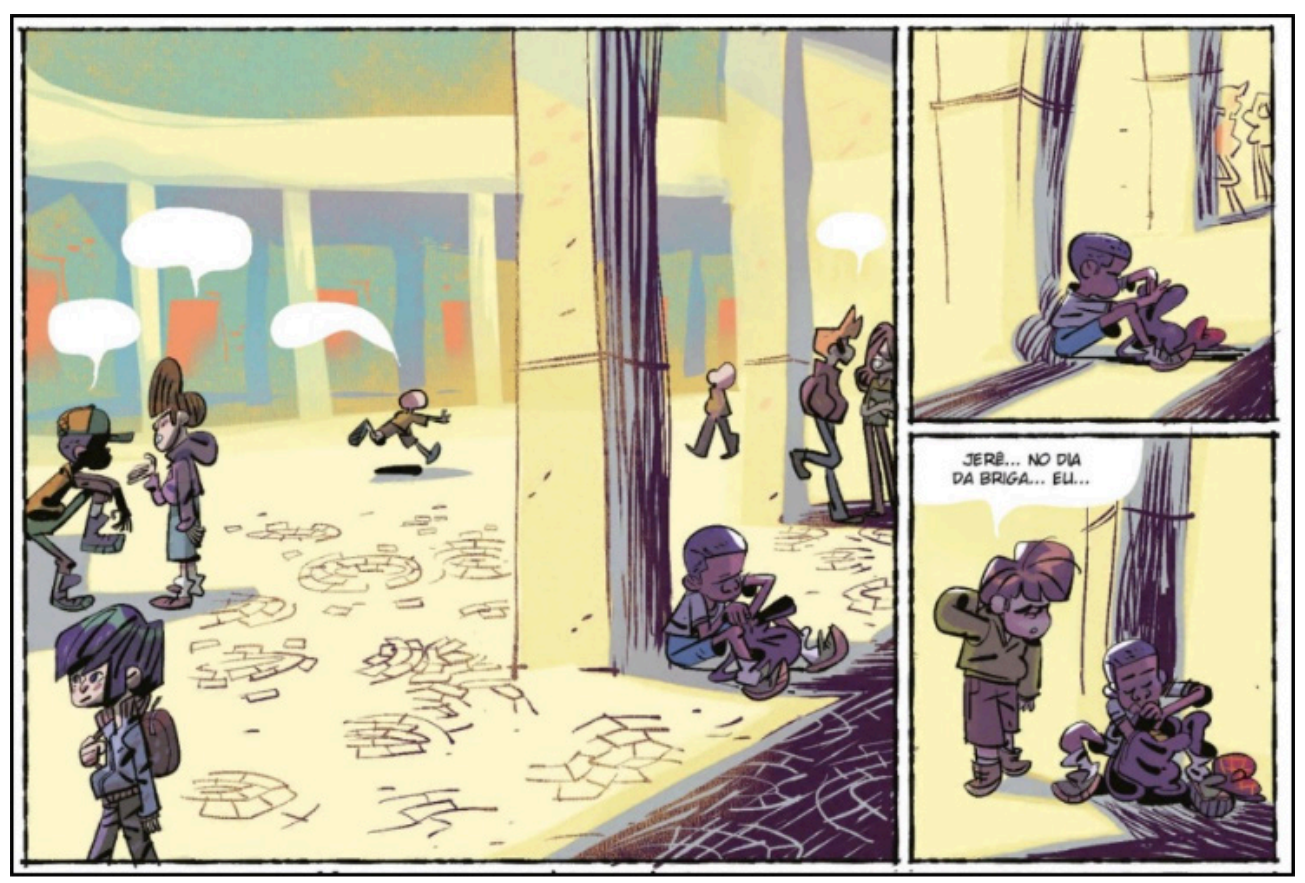

Figura 17: quadro ilustrado, Jefferson Costa. Jeremias Pele. São Paulo: Panini, 2018.

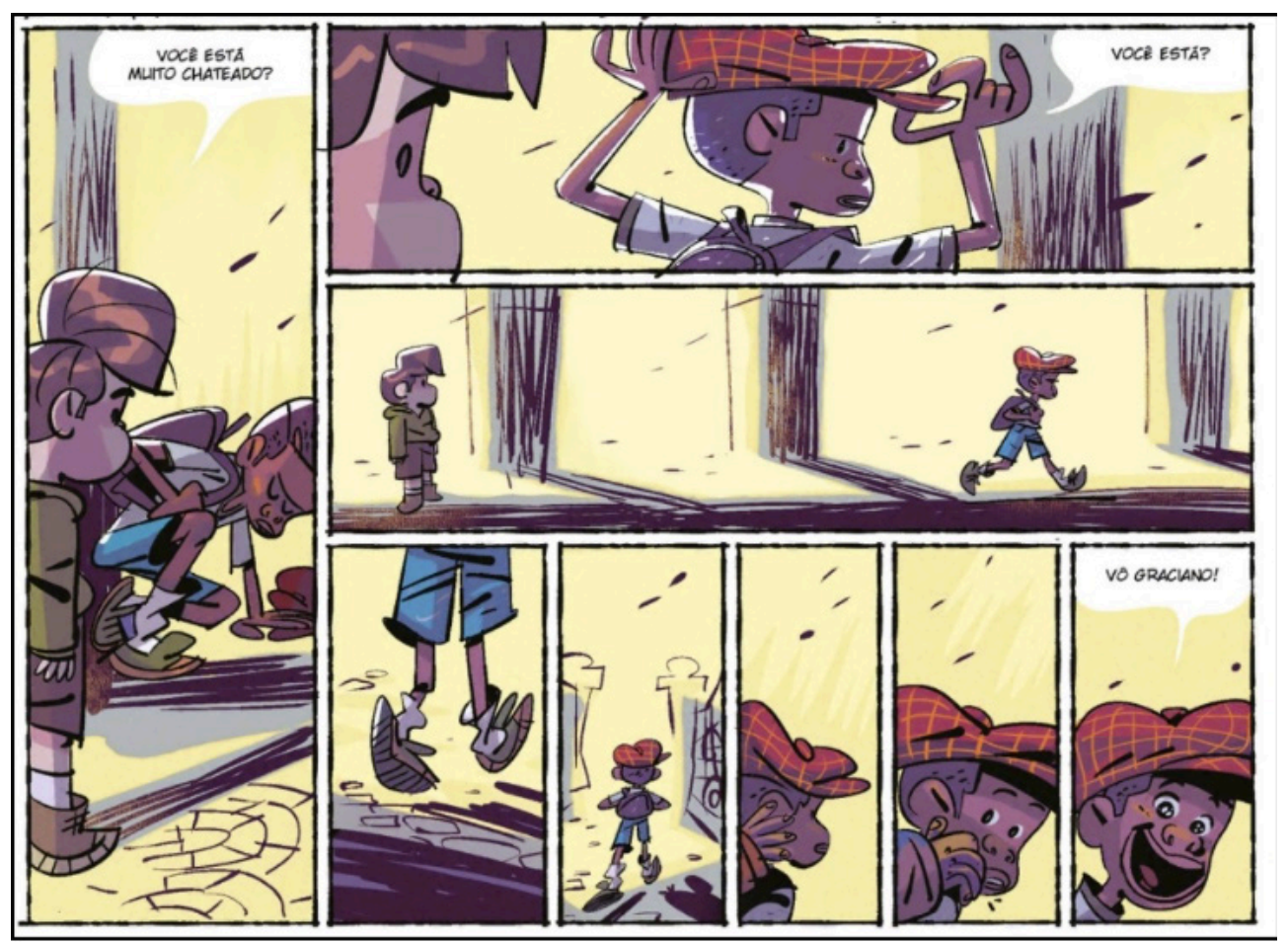

Figura 18: quadro ilustrado, Jefferson Costa. Jeremias Pele. São Paulo: Panini, 2018. 


\section{Conclusão}

Muitos podem questionar a classificação indicativa de 12 anos para o livro Jeremias Pele, e também a validade de seu uso em sala de aula, sobretudo por conta da abordagem direta que faz do tema racismo, em que crianças e pré-adolescentes podem se deparar com cenas como a seguinte:

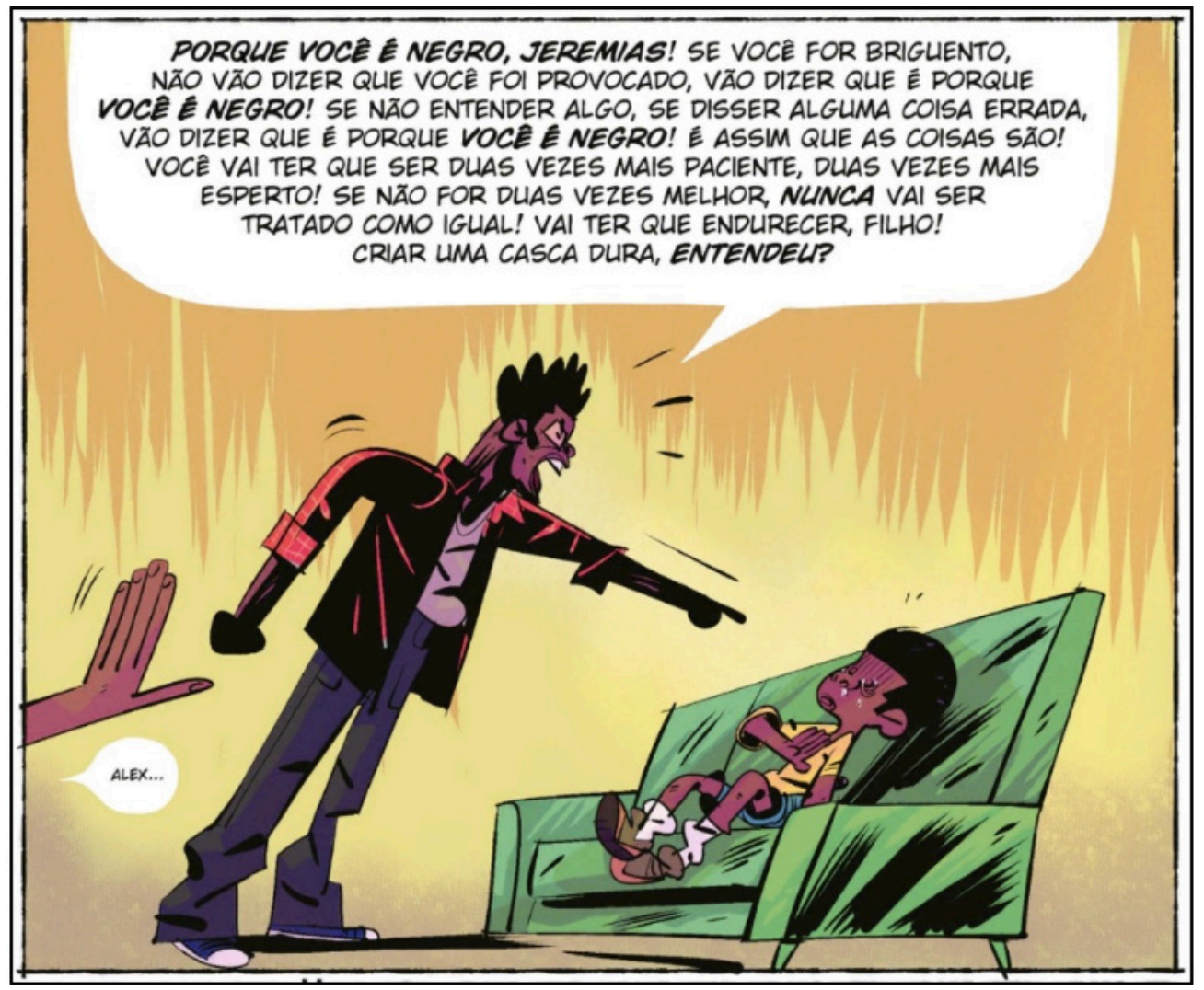

Figura 19: quadro ilustrado, Jefferson Costa. Jeremias Pele. São Paulo: Panini, 2018.

No entanto não podemos considerar os mais jovens como incapazes de ler e interpretar o mundo à sua volta ou de compreender e questionar a realidade - com esse propósito, inclusive, este artigo sugere que se utilizem passagens do livro para que os alunos discutam sobre como e o quanto crianças podem questionar autoridades e estruturas já estabelecidas.

A escola desempenha diversos papéis e um dos mais notórios e importantes é o da socialização. As crianças e pré-adolescentes necessitam desse espaço a fim de aprender o que é tido como correto e incorreto na sociedade e no meio em que vivem, assimilar os modos aceitáveis e inaceitáveis de conduta - e também serem capazes de questioná-los.

A omissão dos profissionais competentes à apresentação e discussão de assuntos como racismo, 
bullying e exclusão já mostra seus resultados no cotidiano de nossas escolas. Devemos evitar que o ambiente escolar permaneça repetindo as problemáticas das estruturas pré-estabelecidas, sem que haja uma reflexão de nossos jovens quanto a essas questões. É necessário trabalhar para que a escola deixe de ser o ambiente em que minorias sintam os primeiros sinais de exclusão e silenciamento e em que todos os estudantes, de todas as classes e origens, primeiro aprendam a excluir, conforme apontou François Dubet em seu artigo A Escola e a Exclusão (DUBET, 2003). A seguinte citação, retirada da tradução do referido artigo, remete diretamente à situação apresentada na história de Jeremias Pele:

No final das contas, os alunos mais favorecidos socialmente, que dispõem de maiores recursos para o sucesso, são também privilegiados por um conjunto de mecanismos sutis, próprio do funcionamento da escola, que beneficia os mais beneficiados. Essas estratégias escolares aprofundam as desigualdades e acentuam a exclusão escolar na medida em que mobilizam, junto aos pais, algo que não é só o capital cultural, este entendido como um conjunto de disposições e de capacidades (...). (DUBET, 2003, p. 36)

No episódio vivido pelo protagonista, vemos o que parece ser uma simples atividade de redação abrir precedente para que uma criança seja hostilizada pelos colegas e negligenciada por sua professora, e, assim como apontado na citação anterior, o resultado só é positivo graças ao apoio e formação cultural, não apenas dos pais de Jeremias, mas também de seu avô. Essa, infelizmente, não é a realidade da maioria das crianças e adolescentes oriundos de grupos historicamente excluídos; assim Dubet encerra seu texto destacando que a escola outrora representou um lugar de refúgio aos menos favorecidos, mas hoje integra os mecanismos de exclusão:

O problema da exclusão nos ensina que as relações da escola e da sociedade se transformaram e que a escola perdeu sua "inocência". Ela própria é o agente de uma exclusão específica que transforma a experiência dos alunos e abre uma crise de sentido nos estudos, às vezes até da legitimidade da instituição escolar. A escola convida, um século após a formação da escola republicana, a nos interrogarmos sobre as finalidades da educação. Com efeito, a exclusão escolar é o resultado "normal" da extensão de uma escola democrática de massa que afirma ao mesmo tempo a igualdade dos indivíduos e a desigualdade de seus desempenhos. Nesse sentido, a escola integra mais e exclui mais que antes, apesar de seus princípios e de suas ideologias, e funciona cada vez mais como o mercado, que é, em sua própria lógica, o princípio básico da integração e da exclusão. (DUBET, 2003, p. 44. Aspas do autor). 
A perda da "inocência", mencionada por Dubet, aponta para a responsabilidade atual da escola de questionar esse funcionamento "cada vez mais como o mercado", trazendo para o seu ambiente discussões sobre respeito às diferenças e convívio com as pessoas, mostrando às crianças e adolescentes que esses também são aspectos do desenvolvimento dos educandos. As escolas devem estar preparadas para transmitir esses valores tanto quanto o ensino do currículo escolar e da cultura institucional. O uso das histórias em quadrinhos em sala de aula pode ser um importante aliado na introdução e debate desses aspectos.

Essas características se apresentam sobretudo nas histórias produzidas para os adolescentes, que trazem muitas referências atuais e do cotidiano, tratando de temas sérios como política, guerras e questões sociais como gênero, raça e sexualidade. Jeremias Pele apresenta o personagem tradicional no contexto atual das questões raciais e também em uma narrativa mais realista, contudo ainda lúdica, em relação à Rua do Limoeiro - ambiente descrito como ideal pelo próprio criador, Maurício de Souza, no prefácio da obra abordada neste artigo.

Desse modo, os quadrinhos se apresentam como alternativa para um ensino prazeroso e funcional, indo ao encontro das ideias de Libâneo em seu artigo "O dualismo perverso da escola pública brasileira: escola do conhecimento para os ricos, escola do acolhimento social para os pobres":

\footnotetext{
Nessa condição, a escola é uma das mais importantes instâncias de democratização social e de promoção da inclusão social, desde que atenda à sua tarefa básica: a atividade de aprendizagem dos alunos. Tal aprendizagem não é algo natural que funciona independentemente do ensino e da pedagogia. As mudanças no modo de ser e de agir decorrentes de aprendizagem dependem de mediação do outro pela linguagem, formando dispositivos internos orientadores da personalidade. (LIBÂNEO, 2012, p. 26. Itálico do autor).
}

\section{Referências Bibliográficas}

CALÇA, Rafael, COSTA, Jefferson. Jeremias Pele. São Paulo: Panini, 2018.

BORSA, Juliane Callegaro. O papel da Escola no Processo de Socialização Infantil. Disponível em: link https://www. psicologia.pt/artigos/textos/A0351.pdf. Acesso em: 21 fev. 2020.

CARVALHO, Djota. A Educação Está no Gibi.Campinas: Papirus,2006.

COSTA, Vera Lucia Pereira da. A Função Social da Escola. 2012. Publicação online, disponível em: http://www. drearaguaia.com.br/projetos/funçãosocialescola.pdf. Acesso em: 21 fev. 2020. 
DUBET, François. “A Escola e a Exclusão” Trad. de Neide Luzia Resende, in Cadernos de Pesquisa, n. 119, p. 29-45, 2003. Disponível em: http://www.scielo.br/pdf/cp/n119/n119a02.pdf. Acesso em: 21 fev. 2020.

FAZENDA, Ivani CA. Didática e Interdisciplinaridade. Campinas: Papirus, 1998.

FIGUEIRA, Diego. RAMOS, Paulo. VERGUEIRO, Waldomiro. Quadrinhos e Literatura Diálogos Possíveis. São Paulo: Criativo, 2014.

FÔNSECA, Dan Lurie Tavares, CUNHA, Ana Cristina Elias da, SILVA, Robson Campanerut da. "Educação, paternalismo e clientelismo: identificando o aprendizado de sala de aula nas questões sociopolíticas." in Anais IV Congresso Nacional de Educação, Editora Realize, 2019. Disponível em: https://editorarealize.com.br/revistas/conedu/ trabalhos/TRABALHO_EV073_MD1_SA11_ID3226_22092017075215.pdf.Acesso em: 21 fev. 2020.

LIBÂNEO, José Carlos. "O dualismo perverso da escola pública brasileira: escola do conhecimento para os ricos, escola do acolhimento social para os pobres." in Educação e Pesquisa, São Paulo, v. 38, n. 1, p. 13-28, 2012. Disponível em: https://doi.org/10.1590/S1517-97022011005000001.Acesso em: 21 fev. 2020.

SOURIAU, E. A Correspondência das Artes: Elementos de Estética Comparada. Trad. Maria Cecília Queiroz de Moraes Pinto e Maria Helena Ribeiro da Cunha. São Paulo: Cultrix/Edusp, 1983.

VERGUEIRO, W. “Quadrinhos e Educação Popular no Brasil”. in Muito Além dos Quadrinhos: Análises e Reflexões Sobre a $9^{a}$ Arte. São Paulo: Contexto, 2009.

WESCHENFELDER, Gelson Vanderlei, ANDREOLA, Balduino Antonio. "Histórias em quadrinhos e seu uso como objeto pedagógico" in Universidade e Responsabilidade Social - Inovações Pedagógicas e Tecnológicas na Educação. Jundiaí: Paco Editorial, 2015. Disponível em: https://www.researchgate.net/publication/308978789_HISTORIAS_ EM_QUADRINHOS_E_SEU_USO_COMO_OBJETO_PEDAGOGICO. Acesso em: $21 \mathrm{fev} .2020$. 